\title{
CONVERSAS AO PÉ DAS ÁRVORES: \\ EXPERIÊNCIAS DIALÓGICAS COM A LITERATURA NOS ANOS INICIAIS DO ENSINO FUNDAMENTAL
}

\author{
TALKS UNDER THE TREES: \\ DIALOGICAL EXPERIENCES WITH LITERATURE IN THE EARLY YEARS OF \\ ELEMENTARY SCHOOL
}

\author{
Maria Fernanda Alvito Pereira de Souza Oliveira ${ }^{1}$ \\ Denise Barreto de Resende ${ }^{2}$
}

\begin{abstract}
Resumo: Este trabalho busca inserir-se nas discussões atuais sobre literatura e educação, tomando como objeto de estudo a prática docente de uma professora regente do primeiro segmento do ensino fundamental. Duas situações de leitura serão analisadas, com foco nos livros A Árvore Generosa (SILVERSTEIN, 2003) e A Árvore das Lembranças (TECKENTRUP, 2014). O percurso formativo da professora é tematizado, fornecendo o contexto e apontando para a motivação de seu empenho na constituição de um espaço privilegiado para a leitura e a conversa sobre textos literários na rotina das ações docentes e discentes.
\end{abstract}

Palavras-chave: literatura; educação; formação.

Abstract: The aim of this work is to be inserted in the current discussions about literature and education, concerning a primary school teacher's practice. Two reading moments will be analysed, focusing on A Árvore Generosa (SILVERSTEIN, 2003) e A Árvore das Lembranças (TECKENTRUP, 2014). The teacher's education process as theme, providing context and leading to motivate her into creating a privileged space for reading and talking about literary texts in the teacher's and learners`actions routine.

Keywords: literature; education; teacher`s education.

\section{Introdução}

Gostaríamos de fornecer ao leitor deste trabalho um esclarecimento inicial sobre a sua autoria e forma de enunciação. Escrito por duas professoras, ele resulta de um esforço em parceria para, após as situações vividas, interrogá-las, atribuir-lhes sentidos e experimentar desdobramentos, tanto no espaço escolar quanto no de formação continuada. Assim, optamos por escrevê-lo na primeira pessoa do plural, correspondente a esse momento de investigação e trabalho conjunto. Dessa forma, restou-nos a opção, um tanto incômoda de, quando se trata de

\footnotetext{
${ }^{1}$ Doutora em Letras Vernáculas pela Universidade Federal do Rio de Janeiro. É professora na Faculdade de Educação da Universidade Federal do Rio de Janeiro. mariafernandaapsoliveira@ gmail.com

2 Graduada em Pedagogia pelo Centro Universitário Anhanguera em São Paulo. Professora de Ensino Fundamental da Secretaria Municipal de Educação do Rio de Janeiro. deniseresende @rioeduca.net
} 
fazer referência a uma de nós e a seu trabalho, usar a terceira pessoa. Apesar do efeito de distanciamento que essa forma de abordagem pode produzir, pareceu-nos a melhor solução para a exposição que necessitamos fazer.

Desde o ano de 2016, a professora Denise participa de Encontros de Professores para Estudos de Letramento, Leitura e Escrita (Epelle). Este espaço, inaugurado em 2011 e coordenado pela professora Ludmila Thomé de Andrade, da Faculdade de Educação da UFRJ, define-se como o de uma pesquisa-formação, na qual se desenvolve o objetivo de levar os professores a escreverem sobre suas práticas. No ano de 2018, o Epelle dedicou-se às questões de ensino e aprendizagem de literatura, com o convite à professora Maria Fernanda para integrar temporariamente a coordenação. No primeiro semestre, funcionamos como um grupo de estudos, formado por três professores universitários, uma professora de Educação Infantil, duas de Ensino Fundamental I e uma de Ensino Fundamental II. No segundo, sob a forma de curso de extensão, a turma de professores se expandiu, mantendo, porém, a mesma rotina de trabalho. Ao lado dos estudos teóricos, realizávamos leituras literárias e apresentávamos nossas práticas docentes para a reflexão coletiva, na intenção de formular e conduzir questões dignas de pesquisa e investimento docente, bem como de possível compartilhamento no ambiente acadêmico. A colaboração entre as autoras deste estudo iniciou-se nesse contexto, cuja abordagem é também pertinente para o tema de que pretendemos tratar.

\section{Para que serve a literatura?}

Há algum tempo, o lugar da literatura na educação escolar vem sendo objeto de intensa discussão no meio acadêmico, enquanto que, para os professores do ensino básico, é perceptível o status frágil de sua presença. Repercutindo mudanças culturais e sociais profundas nas sociedades contemporâneas, a questão da leitura literária tem dividido opiniões e dado lugar a embates nos espaços decisórios das políticas curriculares, como temos assistido, no Brasil, pelo menos, desde a publicação dos Parâmetros Curriculares Nacionais. Talvez o risco do apagamento da literatura em meio à diversidade discursiva com que se pretende familiarizar os alunos na atualidade não permita de fato fazer prognósticos esperançosos para a sua permanência em nossas escolas, como sublinha Regina Zilberman (2009) em um de seus artigos. Segundo a autora, na escola das classes populares, destinada à formação para o mercado de trabalho, só uma motivação de caráter pragmáticopoderia justificar o esforço pela formação de leitores literários. Assim, na esteira da argumentação que 
defende o domínio da norma cultada língua como instrumento de luta contra a discriminação e por condições de disputa por parte dos desfavorecidos pela origem social, seria possível pensar que a aquisição de algum conhecimento literário seria mais uma das maneiras de aparelhar os estudantes pobres para a sobrevivência na sociedade competitiva em que vivemos. Trata-se, como se vê, de um argumento de pouca força, pois sabemos que diversas outras manifestações verbais oportunizam, quem sabe de forma mais eficaz, a apropriação dessa variedade linguística. A outra alternativa apontada para a manutenção da formação literária parece ainda mais improvável, já que dependeria da reunião dos filhos das classes mais abastadas com as crianças de classe popular na mesma escola pública, que então seria chamada a responder às expectativas dos setores dominantes, incluindo a literatura como objeto de atenção. Ao lado dessa visão sombria, numerosos trabalhos têm se dedicado a retomar fundamentos para apontar a contribuição da leitura literária para a formação integral do sujeito individual e social. A plasticidade formal e diversidade temática da literatura ao longo dos tempos, longe de serem um reflexo da história, testemunham, como sublinham Todorov (2009) e Colomer (2007), entre outros, o olhar crítico e criador da humanidade sobre si mesma, que assim se oferta para a compreensão e reconfiguração por parte das novas gerações. Mais do que legítimo do ponto de vista ideológico, se temos em vista a formação de uma sociedade democrática, de sujeitos críticos e cidadãos individual e politicamente capazes de ação, éno entantoincerto o futuro desse argumento no balanço dos interesses que movem os projetos educacionais em curso, sobretudo se pensamos no Brasil atual. Entretanto, para os que acreditam, como nós, na potência formativa da literatura, a própria crise que atinge seu lugar como conteúdo de ensino não deixa de, contraditoriamente, intensificar motivações para o trabalho, ao mesmo tempo que exige a assunção clara de nossa posição na controvérsia. Nesse contexto, faz-se necessário que, no nível micro de nossa rotina como docentes, experimentemos e analisemos nossas práticas, buscando responder para que serve a formação de leitores na escola e também na universidade, a quem cabe preparar os responsáveis por essa formação.

"Para que serve a literatura em uma sala de aula do ensino fundamental I" será então a questão condutora a que este trabalho buscará responder, trazendo dois momentos de leituracomo objetos de estudo. Os registrosforam colhidos no ano de 2018, na turma de segundo ano que tinha a professora Denise como regente, em uma escola municipal do Rio de Janeiro. 


\section{Entre sujeitos, profissionais e literatura}

A professora Denise, responsável pelas práticas a serem em seguida analisadas, reconhece ter havido uma mudança de orientação em sua prática ao longo do ano em que participou dos encontros de formação dedicados aos estudos literários (Epelle). Não que a literatura fosse estranha à sua rotina de trabalho, mas não lhe parecia tão fundamental à educação de seus alunos como hoje. A participação nesse espaço trouxe seu interesse para as transformações desencadeadas nos sujeitos no momento da leitura compartilhada de textos literários, em paralelo com as realizadas nos encontros na universidade, que se faziam acompanhadas do estudo teórico sobre o mesmo processo. Assim sendo, para buscar compreender esse efeito de consequências significativas para a reconstrução de seu fazer docente, devemosatentar para a própria experiência leitora que moveu sua mudança de compreensão no nível do vivido, além do intelectual. Embora não tão nova como dinâmica para alguns de nós, tratava-se de uma aproximação coletiva ao discurso literário, algo que nem sempre encontra tempo e espaço em nossodia-a-dia pessoal e profissional. Tal processo, bem próximo do que vivem os alunos em momentos de compartilhamento de leitura em sala de aula, pode ser pensado, segundo cremos,em dois níveis interdependentes - como apropriação cultural e como experiência subjetiva.

No primeiro nível, temos a ideia, difundida nos estudos linguísticos, de que a ampliação de nossas práticas de linguagem depende da imersão em ambientes sociais em que essas práticas vigoram. Como atestam várias pesquisas sobre as dificuldades do ensino de gêneros na escola (ROJO; BARBOSA, 2015; SIGNORINI, 2007; MARCUSCHI, 2008, entre outros), sabemos que não basta o contato com os textos de uma determinada esferade atividades e linguagem para nos aproximar da natureza do discurso aí praticado. $\mathrm{O}$ desenvolvimento de nossos recursos e comportamentos linguísticos está ligado à nossa integração a espaços socialmente delimitados de relacionamento, marcados por objetivos, valores e modos de agir, com outros que a eles estão afeitos. É essa dinâmica sociocultural que, situando-nos como atores, pode dar lugar à modulação de nossa própria recepção e produção de enunciados singulares em meio a um determinado ambientesocial e discursivo. Por isso é tão difícil ensinar a heterogeneidade discursiva na escola, dada a estrutural condição de isolamento social que marca essa instituição que funciona entre muros e de portões fechados. Desse modo, ao selecionar textos e compartilhá-los em nossas reuniões, 
formávamos uma pequena comunidade de leitores e seguíamos uma rota possível para dar sentido à literatura como prática social e discursiva, como modalidade de ação e interação humana. Por meio da leitura coletiva,diversificávamos e aprofundávamos nosso pertencimento a essa esfera cultural.

Para falar do segundo nível, basta apontar que, nesse ambiente, como não poderia deixar de acontecer, compareciam os saberes construídos em nossas histórias leitoras, e assim se reeditavam algumas das funções que a literatura tem assumido socialmente, dentre as quais a de produtora de efeitos de subjetivação, na leitura. Dessa forma, os próprios modos historicamente construídos de ler literatura, que dão sentido à leitura literária como um empenho da sensibilidade em sua própria expansão e transformação, eram ali não somente reeditados, mas, expondo-se uns à vista dos outros, também confirmados e fortalecidos. Tratando-se de leitura compartilhada,as ressonâncias pessoais e os efeitos subjetivos eram visibilizados pela discussão, onde se ressaltavamdiferenças de percepção que, em um contexto de troca distensa, amigável, acrescentava prazer às descobertas, aqui não separáveis, do texto e do outro, parceiro de leitura.Ora, como já observamos, cabe reconhecer que esse tipo de encontro desinteressado do ponto de vista pragmático e, por contraste, tão interessante do ponto de vista das vivências que desperta entre os participantes, é algo raro, mesmo entre pessoas ditas cultas em nossa sociedade. Talvez por isso tenha produzido tanto impacto para a professora Denise, como leitora e professora para quem a leitura ganhou doravante um sentido de encontro consigo e com o outro que tocou fundo no sentido de educar por ela assumido, passando a direcionar parte de seu empenho no fazer docente e sua busca de conhecimento. Nesse contexto,nossa parceria nasceu marcada por um laço não restrito à técnica ou ao trabalho conceitual, o que não deixa de ser relevante sublinhar, falando de formação de professores e de literatura!

Numa rotina constituída pela prática docente e pela participação em um espaço de formação composto de pares, os processos vividos em um e outro podem ser semelhantes ou intervir um sobre o outro. Assim, ao mesmo tempo que as experiências do grupo de formação desaguavamde algum modo na sala de aula, que se fazia também permeada de gestos e ditos de colegas leitores e professores, a narrativa dessa prática, ao retornar ao espaço entre pares, produzia reações intensas -- um outro tipo de fruição, coletiva, na contemplação da forma que assumiam algumas propostas de trabalho ali germinadas - e também novos desafios e questões. Dessa forma, as experiências de leitura na escola relatadas e discutidas a seguir se 
encontram ligadas originariamente às vividas no grupo de formação, ao mesmo tempo queeste texto, como elaboração reflexiva, deve a elas o conhecimento que possa contribuir para construir.

Como vimos, a dinâmica da leitura compartilhada tem a vantagem de esclarecer o próprio processo de leitura em uma dimensão importante, a da construção subjetiva e diferenciada do texto por cada leitor. Para além disso, a experiência do encontro com o outro que, na mesma medida, ela potencializa, descortina um novo horizonte de trabalho, de caráter social, que as experiências de sala de aula viriam a confirmar e cujas implicações cumpre explorar em novas proposições didáticas e de pesquisa.

\section{Leitura literária: experiências dialógicas}

Em $A$ arte de ler - ou como resistir à adversidade, Michèle Petit (PETIT, 2008) apresenta o próprio mediador como um primeiro objeto de interesse do leitor em formação, em uma dinâmica que é movida pelo afeto. Da importância atribuída ao livro por um outro privilegiado -- um professor, a mãe, um amigo e, podemos acrescentar, um colega de trabalho -- depende o interesse inicial daquele que dele se aproxima. Como objeto de desejo desse outro, ele se insere no horizonte de possíveis experimentações do futuro leitor. Portanto, a disposição do leitor para o encontro com o texto depende ao mesmo tempo da garantia e da provocação que o mediador é capaz de oferecer, apoio e impulso para o risco que a lançar-se à leitura sempre implica. Talvez isso valha para todo saber, não somente a literatura. De qualquer modo, é necessário destacar que os diálogos a seguir pertencem a um contexto permeado por afetos entre alunos e professora. A turma em questão vinha de experiências desalentadoras na escola, tendo sido considerada uma turma difícil de trato e com problemas de aprendizagem. Havia tido diversos professores e entrava, nesse momento, em uma nova fase, de confiança estabelecida e parceria com a professora Denise, que aceitara o desafio de construir com os alunos um espaço de convívio e trabalho. Havia, portanto, desde algum tempo, uma disposição positiva dos alunos em relação às propostas da professora. A leitura literária já se tornara parte da rotina diária, e um importante projeto, que deu origem a um livro $^{3}$ composto pela turma, precedeu as situações aqui relatadas. As rodas de leitura, em que todos eram chamados a fazer seus comentários aos livros, durante e depois da leitura, já

${ }^{3}$ Livro digital disponível em: https://pt.calameo.com/read/005670219e9e4f6cf7c15?fbclid=IwAR0rWhhgRVr0bpkY7UmtowGcvbvh8b3W4eiOVTZGzD1nNmBEjYWMztMcmM 
haviam se tornado momentos apreciados e respeitados pelos alunos, e os diálogos, no período em questão, tornavam-se cada vez mais animados. Assim sendo, pode-se dizer que, não sendo leitores experientes, os alunos não eram completamente iniciantes nos comportamentos característicos desse momento de troca. Exploravam com a energia da novidade a riqueza dessa experiência que só nesse ano se lhes tornava mais familiar. São também diálogos coordenados por uma professora que, como sublinhamos antes, vivenciava um momento de crescente interesse pelo discurso e pelas relações estabelecidas em torno do texto literário e, portanto, para ela, como mediadora, também carregavam algo de novidade.

\subsection{Conversas ${ }^{4}$ sobre A Árvore Generosa (SILVERSTEIN, 2003).}

Prof $^{a}$ : Bom dia crianças! Hoje vou ler um livro que a minha prof ${ }^{a}$ Maria Fernanda me emprestou. O nome do livro é A Árvore Generosa.

Turma em silêncio. A leitura começa.

"Era uma vez uma árvore... que amava um menino. E todos os dias o menino vinha, juntava as suas folhas e com elas fazia coroas, imaginando ser o rei da floresta. Subia o seu tronco, balançava-se nos seus ramos, comia as suas maçãs, brincavam às escondidas e quando ficava cansado, dormia à sua sombra. O menino amava aquela árvore... como ninguém. E a árvore era feliz."

A turma continua em silêncio. A professora prossegue.

"Mas o tempo passou. O menino cresceu. E a árvore ficava muitas vezes sozinha. Um dia o menino veio e a árvore disse-lhe: - Anda, menino. Anda subir o meu tronco, balançar-te nos meus ramos, comer maçãs, brincar à minha sombra e ser feliz. - Já sou muito crescido para brincar - disse o menino. - Quero comprar coisas e divertir-me. Quero dinheiro. Podes dar-me algum dinheiro? - Desculpa - disse a árvore. - Eu não tenho dinheiro. Só tenho folhas e maçãs. Leva as minhas maçãs, menino. Vende-as na cidade. Então terás dinheiro e serás feliz. E assim, o menino subiu o tronco, colheu as maçãs e levou-as. E a árvore ficou feliz."

A turma começa a se mobilizar em defesa da árvore:

Camila: Ah, malandro! Coitada da árvore!

Bia: Ele é um interesseiro! Dá nada pra ele não!

Lívia: E ainda ela fica feliz! Muito boba!

Turma: Ah não! Que isso! Não pode!

A turma continua reclamando. A professora pede silêncio para continuar.

"Mas o menino ficou longe da árvore durante muito tempo... E a árvore ficou triste outra vez. Até que um dia o menino regressou e a árvore, estremecendo de alegria, disse: - Anda, menino. Anda subir o meu tronco, balançar-te nos meus ramos e ser feliz. - Estou muito ocupado para subir a árvores - respondeu o menino. - Eu quero uma casa para viver. Quero uma mulher e filhos. Para isso preciso de uma casa. Podes dar-me uma casa? - Eu

\footnotetext{
${ }^{4}$ Para preservar a identidade dos alunos, os nomes usados são fictícios.
} 
não tenho casa - disse a árvore. - A floresta é o meu abrigo. Mas corta os meus ramos e constrói a tua casa. Então serás feliz. O menino assim fez. Cortou os ramos e levou-os para construir uma casa. E a árvore ficou feliz."

Camila: Pelo amor de Deus! De novo não!

Turma fica agitada, todos falando ao mesmo tempo mostrando-se indignados com a atitude do menino e a da árvore também.

Marcelo: Pra que que ela fica chamando o homem de menino? Ele já cresceu!

Prof : Será que é uma forma carinhosa de falar dele?

Lara: Minha vó diz que filho nunca cresce.

Luan: Mas não é filho dela !?

Bia: Se fosse seria um filho muito ruim!

Mais uma vez a professora pede que se acalmem para continuar a leitura.

"Mas, uma vez mais, o menino separou-se da árvore e quando voltou, a árvore sentiu-se tão feliz que mal conseguia falar. - Anda, menino - sussurrou ela. - Anda brincar. - Estou velho e triste demais para brincar - explicou o menino. - Quero um barco que me leve para bem longe daqui. Podes dar-me um barco? - Corta o meu tronco e faz um barco disse a árvore. - Assim poderás viajar para longe... E ser feliz. O menino cortou o tronco, fez um barco e partiu. E a árvore ficou feliz... Mas não muito."

Camila: Não tia, agora chega! Não quero mais ouvir esta história não.

Turma: Verdade! Também não! Fala sério!

Profa: Calma pessoal, vamos ouvir até o final.

Marcelo: Não sobrou nada dela! Ela vai morrer!

Prof : Posso terminar a leitura?

Neste momento, o ambiente na sala encontra-se muito tenso. Além desses diálogos, a turma como um todo está descontente, e a professora acredita que talvez não consiga terminar a leitura.

Turma não responde nem que sim nem que não.

"Muito tempo depois, o menino voltou novamente. - Desculpa menino - disse a árvore. Nada mais me resta para te dar. As maçãs já se foram. - Os meus dentes são fracos demais para maçãs - explicou o menino. - Já não tenho ramos - lamentou a árvore. - Também já não tenho idade para me balançar em ramos - respondeu o menino. - Não tenho tronco para subires - continuou a árvore. - Estou muito cansado para isso - disse o menino. Desculpa - suspirou a árvore. - Gostava de ter algo para te oferecer... mas nada me resta. Sou apenas um velho toco. Desculpa... - Já não preciso de muita coisa - acrescentou o menino. - Só um lugar sossegado onde me possa sentar e descansar. Sinto-me muito cansado. - Pois bem - respondeu a árvore, endireitando-se o mais possível. - Um velho toco é ótimo para te sentares e descansar. Anda, menino. Senta-te. Senta-te e descansa. E foi o que o menino fez. E a árvore ficou feliz."

Camila: Ah, não gostei desta história não!

Profa: Por quê?

Camila: Tadinha da árvore...

Prof : Pessoal, e no final das contas, o que significa generosa?

Bia: Boa demais!

Renato: Que só faz coisa boa para os outros. 
Prof ${ }^{\text {a. }}$ Vou olhar aqui no dicionário. (Professora pega o celular).

"Generosidade é a virtude de quem compartilha por bondade. Um ato de generosidade deve ser feito de forma desinteressada, sem esperar nenhum retorno." 5

Prof : Entenderam? Ser generoso é dar alguma coisa, é ajudar alguém, sem esperar nada em troca.

Camila: Ah tia! Então ser generoso é muito, muito difícil!

A leitura deste livro ficou marcada na experiência da Professora Denise por sua singularidade. Foi uma experiência diferente. O modo como os alunos reagiram ao texto destacou-se em relação ao de todas as leituras que ela havia realizado até então. Familiarizada com o material de apoio ao professor disponibilizado pelo Programa Nacional de Alfabetização na Idade Certa, o PNAIC, a professora entrara em contato com a proposta das "leituras deleite" aí apresentada. Segundo esse documento norteador, "a leitura deleite é um momento destinado ao prazer e reflexão sobre o que é lido, sem preocupação com a questão formal da leitura. É ler para se divertir, sentir prazer, para refletir sobre a vida" (BRASIL, 2012, p. 29). Nessa orientação para o trabalho dos professores, parece claro que a distinção entre leituras em que há maior controle sobre o processo de aquisição de estratégias de compreensão e outras em que se afrouxa esse controle em benefício de uma relação mais espontânea e vital com a matéria literária visa em princípio garantir tempo para que a literatura seja experimentada em seus sentidos socialmente constituídos de discurso em torno do humano, e humanizador (CANDIDO, 1995; TODOROV, 2009). Por outro lado, também cumpre reconhecer que a expressão carrega conotações que poderiam levar o professor a uma compreensão diminuída da própria literatura e distorcida do trabalho pedagógico a realizar em torno dela. É possível que, deixando-se conduzir por essas conotações, o professor venha a excluir deliberadamente, de sua seleção de textos, aqueles que não considere suficientemente deleitosos para um momento que ele poderia compreender, de forma um tanto limitada, como reservado a uma simples distensão do trabalho escolar considerado sério, um refresco no dia, na rotina de aprendizagens. Ora, esse encaminhamento exclui do trabalho com a literatura justamente a sua potência de transformação, ligada àquela quebra de expectativas que nem sempre é sentida como prazerosa pelo leitor, mas pode ainda assim interessá-lo por um texto, se houver cuidado na mediação. Um tal choque com formas de olhar, sentir e pensar o mundo, amparado e trabalhado na coletividade de um espaço dialógico, comporta uma força de

\footnotetext{
${ }^{5}$ Significado de generosidade disponível em 〈https://www.significados.com.br/generosidade/>
} 
abertura de horizontes e de problematização de certezas que pode dar à leitura compartilhada escolar uma significação pedagógica bastante relevante. Isso se distancia do deleite e se apresenta como experiência formativa do humano em todas as suas dimensões - individual, social, política. Assim parece ter ocorrido na conversa que acabamos de relatar.

Observando-a, percebemos que há um verdadeiro embate da turma com os valores que regem as condutas de ambos os personagens da história. Com o "menino", por ser egoísta e parecer nunca levar em conta a felicidade da árvore, mas somente seus próprios interesses e a própria insatisfação que o conduz ao longo da vida; com a árvore, pelo contrário, por aparentemente nunca pensar em si mesma e estar sempre pronta a satisfazer as necessidades do outro, conquistando na dádiva e no próprio sacrifício a felicidade. É também interessante notar que, durante todo o tempo que durou a leitura e a conversa em torno do texto, os alunos se mantiveram em significativa unidade, não havendo contrastes de apreciação e de recepção relevantes, apenas acréscimos, ampliações de uma mesma perspectiva em nuances diversas. É como se a recepção estivesse mesmo marcada por valores compartilhados, assumidos por todos de forma inequívoca, por um horizonte que o texto força ao deslocamento. E que valores são esses? Parece-nos nítida aqui a força do julgamento moral contra o aproveitador, o "malandro", o indivíduo que só quer se dar bem, "o interesseiro", que só pensa em si e usa o outro em seu próprio e único benefício. Chama a atenção, no entanto, a rapidez com que o julgamento negativo do personagem é manifesto, sem qualquer dúvida e em coro. A isso podem estar ligadas a boa capacidade de compreensão leitora, especificamente de antecipação, no reconhecimento de mudanças de destino anunciadas por meio de marcas de distinção temporal como "Mas o tempo passou", fazendo prever algum revés na harmonia apresentada no primeiro momento da história, em que a árvore e o menino estavam ligados por afeição mútua. Certamente, depois desse tempo passado, a negação, por parte do menino, do convite para "brincar", seguida da revelação aberta do desejo por coisas e dinheiro, é percebida como uma inversão violenta da harmonia anterior e pode-se reconhecer que esse choque é projetado pela obra, cujo narrador não tece comentários, no entanto recorta as situações com hábil manejo dos conectivos - "Mas o tempo passou"... "E a árvore ficou feliz" - assim orquestrando as reações imediatas de seus leitores. Nessa narrativa extremamente econômica, o texto conta com o conhecimento de mundo de quem deve compreender mais do que é dito, dando sentido ao drama que se desenrola entre os dois personagens que, no entanto, nunca brigam. A resposta rápida dos alunos comprova que eles detêm esse 
conhecimento. Sendo crianças num mundo de consumo, têm consciência do quanto ter coisas e dispor de dinheiro para comprá-las são importantes, porque isso faz parte de seu próprio diaa-dia. Em razão disso, é possível pensar que a marca de suas reações tenha a ver com o caráter contraditoriamente sedutor e negativo, para eles, do desejo de muito possuir. Esse apego tão característico de nosso tempo eles parecem enxergar com uma perspectiva própria, uma vez em que a vontade de ser bom, ser amigo, ter consideração pelo outro, também manifesta fazer parte do projeto de vida que as crianças constroem para si e que os adultos sustentam para elas, não sem contradição. Assim, é significativa a forma veemente com que a não reciprocidade do afeto, a falsidade na relação com a árvore, da parte do menino, é condenada. Em determinado momento, a diferença entre ser criança e ser adulto, no que diz respeito às responsabilidades morais nas relações, é tematizada: "Por que ela fica chamando o homem de menino? Ele já cresceu!"--, evidenciando a sutileza com que as crianças sabem aplicar as regras que lhes garantem, durante o tempo da infância, ser julgadas com menos rigidez, embora elas já demonstrem plena noção do certo e do errado, exigindo do adulto a sua posição exemplar nesse sentido.

Com relação à árvore, a distância é outra, e as reações das crianças descrevem um trajeto que pode ser tomado como exemplo de como a conversa literária, defendida por Bajour (2012), é um momento de intenso trabalho de releitura do texto e dos determinantes culturais das reações do leitor diante das situações sociais que ele figura, trabalho que, quando legitimado pelo mediador e pelos participantes, mostra-se capaz não somente de mobilizar afetos, mas também de impulsionar um movimento crítico, muitas vezes exigente, na dimensão das atitudes. Observamos que, de início, os alunos têm apenas pena da árvore, que parece estar sendo enganada pelo menino quando este, pela primeira vez, não vem para estar com a amiga, mas para pedir graças materiais. Há em seguida um momento de crise, que coincide com a descoberta de que a personagem não desconhece a própria situação, e age de acordo com uma decisão que, no entanto, não cabe no entendimento que as crianças têm de relacionamento. Novamente, levando em conta tratar-se de crianças de hoje, neste mundo marcado por individualismo e consumismo, é interessante conjecturar sobre sua indignação com a posição da árvore. Ao contrário do menino, "interesseiro", de início ela é "boba", isto é, estaria sendo passada para trás; depois, sua atitude de deliberada aceitação das demandas do outro em prejuízo próprio se torna verdadeiramente intolerável. Fica a questão sobre os moldes em que estão sendo construídos, nos ambientes em que as crianças crescem, os 
parâmetros considerados normais, aceitáveis, para as relações humanas. Uma hipótese nos leva a supor uma norma implícita ditando que, para lidar com o risco dos muitos malandros que habitam nosso entorno, cada um de nós precisa aprender a não ser bobo, trouxa. Por isso, a atitude abnegada e o contentamento da árvore, considerando que ela não é a vítima de um logro, mas ao contrário, se mostra capaz de enxergar o que se passa consigo e com o seu menino ao longo da vida, se torna insuportável. As crianças não querem nem mais ouvir, o que é sua forma de dizer que não há lugar, no mundo como o entendem, para não se exigir reciprocidade. Entretanto, como o livro desafia os fundamentos dessa diretriz moral, uma vez que obriga o leitor a confrontar-se com a diferença radical entre amor e justiça, há uma dificuldade a ultrapassar. E pelo menos uma aluna a transpõe, quando conclui a sessão de leitura com o comentário que arremata o percurso trilhado com uma precária síntese, não apaziguadora: “Ah tia! Então ser generoso é muito, muito difícil!” Não mais impossível, nem errado e, igualmente importante, também não certo, desejável, ideal, mas apenas uma posição “muito, muito difícill". Eis uma cena de leitura em que a promoção de uma discussão de ordem comportamental, atitudinal, não resulta em prescrição e não descamba para a solução fácil de unificar o sentido a atribuir ao texto, como se de toda a leitura houvesse que extrair, límpida e clara, uma mensagem. O trabalho do dia se encerra, mas a leitura do dia seguinte poderá reabrir o questionamento, retomá-lo de outras formas a partir do que ficou, para todos, ao mesmo tempo mais amadurecido do que antes, mas ainda em aberto, na reflexão sobre o humano que se faz a cada conversa em torno de textos literários. E é justamente o que, algumas semanas depois, virá à tona, junto com outras tantas perplexidades e labutas interpretativas, na leitura que comentaremos a seguir.

\subsection{Conversas sobre A Árvore das Lembranças (TECKENTRUP, 2014).}

A professora Denise encontrou este livro na Sala de Leitura da sua escola. Logo que abriu
e leu a primeira página reconheceu a presença de um tema bastante delicado e difícil de
abordar: a morte. Ao fazer a leitura completa, avaliou que o assunto era tratado com muita
habilidade e cuidado e que seria importante compartilhar o texto com seus alunos. O que
sucedeu durante a leitura foi alguma coisa que ela não pressupôs que ocorresse, já que, para
ela, tudo no enredo da história estava muito claro. Sua perplexidade levou-a a, no mesmo
dia, compartilhar os acontecimentos dessa leitura no grupo de formação, provocando, da
parte das colegas e das professoras coordenadoras, o reconhecimento imediato de que havia
bastante que pensar a partir da conversa em torno do livro.

Prof : Bom dia crianças! Vamos começar com a leitura literária de hoje (Mostra o livro para 
a turma). Como chama o livro?

Alunos em coro: A Árvore das Lembranças.

Marcelo: Será do mesmo da Árvore Generosa?

Bia: Pode ser, o um e o dois. Vai faltar o três. (Professora sorri, mas não responde à pergunta).

Professora abre o livro, deixando ver a primeira página, com texto e ilustração. Logo Marcelo responde:

Não é não. O outro (autor) faz desenho preto e branco, esse aí tá colorido.

Prof : Boa observação Marcelo. O outro autor chama Shell Silverstein, diferente deste (mostrando a capa).

Vamos então. (Todos em silêncio). A professora começa a ler.

"Era uma vez uma raposa que vivia na floresta com outros animais. Ela levara uma vida longa e feliz, mas estava ficando cansada. Bem devagar, ela foi até seu cantinho favorito na clareira. Olhou para sua adorada floresta pela última vez e se deitou. Fechou os olhos, respirou fundo e caiu no sono para sempre."

Neste momento, a aluna Bia interrompe a leitura pela primeira vez, para apresentar um questionamento que tornará a dirigir à professora ao longo de toda a narração e que será responsável pelo desencadear de uma controvérsia entre os alunos, explorando a compreensão e, mais profundamente, a interpretação subjetiva da história para cada um.

Bia: Tia, ela morreu?

Carlos: Não, tá dormindo.

Professora apenas sorri sem querer responder à pergunta. A leitura continua e a história prossegue, contando que, no lugar em que a raposa permaneceu, coberta por um "delicado cobertor de neve", os amigos da floresta, chegando um a um, começam a compartilhar suas lembranças da amiga. São momentos felizes: apostar corrida, olhar o pôr do sol juntos... O terceiro nessa série é o urso.

“... O urso lembrou que a raposa tinha tomado conta dos seus filhotes em certa primavera...”.

Camila: Cuidado, ela pode comer seus filhotes.

Marcelo: Não, ela é generosa.

A narrativa prossegue e outros animais falam, acrescentando cada um uma situação memorável, num trecho que confirma textualmente a suposição do aluno que acabara de falar.

"Cada amigo foi relembrando os momentos especiais que tinha vivido com a raposa. Com sua ternura e generosidade, a raposa havia deixado sua marca na vida de cada um dos animais da floresta, e eles sorriam ao se lembrar dela."

"Enquanto eles conversavam, uma plantinha laranja brotou na neve, bem no lugar onde a raposa tinha se deitado. Era pequena e delicada, quase não dava pra ver, mas a cada história contada ela crescia, ganhando força e ficando bonita."

Nesse momento, alguns alunos da turma pedem esclarecimentos e há um debate. A aluna que formulara a primeira questão sobre a morte da raposa repete-a, ainda não satisfeita.

Gustavo: Tia, ela dormiu, morreu ou virou árvore?

Lara: Ela dormiu, morreu e virou árvore!

Débora: Ela foi pra outro lugar.

Lara: Ela morreu! Não tá vendo que eles estão tristes e com saudades?

Débora: E precisa morrer pra sentir saudade de alguém?

Camila: Ela morreu que nem o meu avô, dormindo. Mas meu avô morreu dormindo no sofá.

Bia: Tia, ela morreu? 
Professora continua sorrindo sem responder à pergunta. A leitura continua, dando a saber que os animais passam a noite na floresta, período em que a planta se transforma em uma pequena árvore.

"Nos dias, nas semanas e nos meses seguintes, os animais recordaram muitas histórias vividas com a raposa. E o peso da saudade que sentiam no peito foi diminuindo. Quanto mais lembravam dela, mais a árvore crescia e ficava bonita, até se tornar a mais alta da floresta. Uma árvore feita de lembranças e repleta de amor."

Novamente surgem dúvidas. Desta vez a ilustração parece ser convocada, como um elemento constituinte da narrativa, para fortalecer o argumento de que a personagem está viva, uma vez que há uma imagem da raposa ereta, de olhos abertos, na floresta. A discussão se complexifica, e a indecisão persiste.

Bia: Tia, ela morreu?

Gustavo: Não tô entendendo nada, ela morreu ou não?

Alex: Ela fugiu, foi morar em outro lugar!

Débora: Por que ela iria fugir se tava feliz?

"A árvore da raposa era tão grande e forte que podia abrigar todos os bichos. E estava sempre cheia de vida (...) A árvore deu força a todo mundo que tinha amado a raposa."

Para alguns, é o momento de concluir.

Lara: Tia, entendi. Ela se foi e as lembranças ficaram na cabeça e no coração!

"E, assim, a raposa continuou para sempre viva em seus corações."

Então, a aluna que dera início à polêmica em torno do acontecimento inicial do enredo decide modular sua interrogação, não respondida de outras vezes, perguntando:

Bia: Tia, qual a sua opinião?

Ao que a professora responde:

Prof : Eu acredito que ela tenha morrido sim, mas continua viva na memória dos amigos. A árvore ficou como uma boa lembrança dela.

Todos em silêncio...

Prof : E aí Carlos, o que você achou?

Carlos: Eu gostei, mas ela tá dormindo.

A discussão dessa leitura vai exigir uma consideração especial em torno das capacidades de compreensão textual em desenvolvimento na turma. Aparentemente, é nesse nível que se dá a dúvida em torno da qual giram muitos dos comentários dos alunos. Mas, levando em conta que, na leitura que apresentamos em primeiro lugar, eles não somente não apresentam dificuldades dessa ordem, mas ao contrário emprestam ao texto sua visão de mundo, indo além do dito para julgar as intenções dos personagens, os impasses aqui encontrados parecem merecer uma reflexão mais detida. É certo que há metáfora no modo como é apresentada a morte da personagem; que, na primeira página, pode gerar dúvida para os leitores infantis a imagem da raposa ereta, num espaço coberto de neve e cercado de árvores, o que, para um leitor mais experiente e advertido por certas marcas do texto verbal, poderia remeter à chegada da personagem ao seu "cantinho favorito na clareira", onde se deita para acolher a morte. No entanto, não parece exagerada a suposição de que a grande 
dificuldade de parte da turma em aceitar a hipótese da morte como um fato do enredo, que faz a discussão circular em torno desse ponto, pode ter tido uma motivação que ultrapassa a (in)capacidade de compreensão dos grandes traços da história a partir das indicações textuais oferecidas. Embora compreensível, uma vez que há, neste segundo texto, aspectos mais opacos para os alunos - como o tempo verbal mais que perfeito (ela levara uma vida longa e feliz), ou a fórmula "caiu no sono para sempre", além do próprio fato de uma história começar pela morte da própria protagonista - a dúvida com relação ao que ocorre à raposa parece-nos estar ligada a dois componentes distintos de sua compreensão do mundo. Por um lado, os alunos parecem reagir com fundamento em sua cultura literária, em que são mais frequentes histórias em que as dificuldades, inclusive a morte de um parente próximo, são superadas pelo personagem principal, culminando em um final feliz; por outro, surge nas falas a própria incapacidade de alguns para aceitar a ideia da morte como um fato irremediável.

No que se refere ao desenvolvimento das capacidades leitoras em sentido geral e da formação específica do leitor de textos da esfera literária, alguns passos da sessão de leitura devem ser sublinhados. O momento inicial, em que a semelhança dos títulos leva a uma comparação com a leitura de A árvore generosa. A observação sobre a diferença nos moldes da ilustração deixa claro o quanto a entrada das crianças no universo literário, realizada por meio do contato com álbuns e livros ilustrados, as caracteriza como leitores multiletrados (ROJO; MOURA, 2012). A referência a séries de livros - "Pode ser, o um e o dois.Vai faltar o três." - aponta não só para os conhecimentos que detêm do universo literário, estritamente falando, mas também do cinema e cultura audiovisual, em que são frequentes as narrativas seriadas. Com relação ao processo de inserção dos alunos nesse amplo conjunto de produções em que a literatura se situa, o momento em que dois alunos discutem sobre o caráter da raposa da história nos oferece um aspecto que interessa discutir. Quando o urso apresenta suas lembranças, dizendo que a raposa um dia tomara conta de seus filhos, uma das alunas, lançando mão de seu conhecimento literário, principalmente de fábulas, em que tantas vezes a raposa simboliza a astúcia egoísta, dirige-se, talvez em tom de brincadeira, ao próprio personagem, para adverti-lo do perigo. Como resposta, um colega, para quem provavelmente a comparação anteriormente tematizada entre os títulos e as obras reativara a leitura anterior de A árvore generosa, se manifesta para afirmar que "não, ela é generosa", em consonância com os traços efetivamente projetados sobre a personagem principal da narrativa que no momento acompanham, o que, logo após, o texto confirma. Este intertexto singular, 
inteligível somente no contexto da comunidade de leitores formada pelos integrantes da turma, testemunha o desenrolar coletivo da formação dos leitores que tem lugar na sala de aula. O compartilhamento de referências e o amadurecimento das questões humanas por meio da diversidade de leituras coletivas caracteriza uma forma consequente, potente, de apropriação do discurso literário em sua significação social, fenômeno a que a escola, de forma privilegiada, pode dar lugar. Identificando partilhas já constituídas e outras por fazer, a partir desta cena de leitura, haveria a possibilidade de explorar um intertexto que quem sabe ajudasse os alunos a elaborar sua interrogação sobre a morte. Como sabemos, a versão alemã de "Cinderela", estabelecida pelos Irmãos Grimm, apresenta o mesmo tópico de uma árvore regada com as lágrimas da perda, neste caso da mãe da menina, que cresce com poderes mágicos, algo comparável ao que ocorre com esta árvore das lembranças, protegendo frondosa os amigos que ficaram. O tema da potência do amor e do contraste de sua infinitude com a finitude humana, figurada nos livros infantis também por meio de personagens animais, poderia ser tratado por meio da inserção deste clássico conto de fadas, alargando o que chamamos de cultura literária e fortalecendo nos alunos o sentimento de pertença a um trabalho civilizacional em que a literatura tem papel relevante.

Retomemos agora diretamente a inquietação central que moveu ao longo de toda a leitura a discussão das crianças. Considerando a relação de confiança e afeto existente entre os alunos e a professora, merece destaque a insistência de alguns leitores em requerer, da parte desta, uma resposta clara para a questão colocada, quando parte do grupo demonstrava já ter chegado à conclusão de que o texto trata do luto, da superação da dor da perda por quem fica. “Tia, entendi. Ela se foi e as lembranças ficaram na cabeça e no coração!” Alguns alunos parecem aceitar que é por meio das lembranças e do vigor do amor, que renasce e se fortalece, num processo aqui simbolizado pelo belo desenvolvimento de uma árvore que, significativamente, ganha a cor da raposa, que podemos recuperar algo da unidade de nós mesmos, após vivermos a dor mutiladora da morte de alguém amado. Outros parecem experimentar no momento da leitura uma possibilidade, talvez antes não vislumbrada, e portadora de ameaça. Atentando para o laço afetivo existente entre alunos e professora, podemos reconhecer no retorno da questão sobre a morte ou não da raposa não simplesmente um pedido de esclarecimento sobre o texto, mas também uma espécie de pedido de ajuda na solução de uma dificuldade existencial, pedido que só pode ser dirigido a um adulto especial, alguém importante e confiável. Nesse sentido, a mudança de formulação a que a aluna Bia 
submete sua questão, relatada com emoção e satisfação pela professora, no mesmo dia, aos colegas do grupo de formação, ganha uma importância singular. Denise narra o fato dizendo mais ou menos o que o rascunho elaborado para este texto registra: "Ela queria uma resposta. Eu não queria dar uma resposta. Ela mudou a pergunta, perguntando agora por uma opinião. Achei isso bacana pra caramba". Em termos do seu processo de formação como leitora literária, a menina parece perceber, neste momento, que a "tia" tem uma intenção pedagógica com as leituras que faz em sala. Se ela não responde em definitivo sobre o acontecimento do enredo, possivelmente será porque esse não deve ser o caminho para se fazer uma leitura. Resolve então devolver para a professora a mesma frase que esta costuma dirigir a eles, como quem experimenta a hipótese de que, com esse tipo de leitura, cabe pensar em termos de opinião e não de verdade. Mesmo que seja ainda cedo para que ela entenda e concorde com o porquê disso, esse é um momento importante, em que a relação com a própria vida pode começar a modular-se por meio da articulação da relação com o adulto, de quem se pode esperar um pouco menos do que a verdade absoluta. Momento de crescimento, de um pequeno passo em direção a uma autonomia que, para cada um de nós, não significa apenas o gozo de uma liberdade, mas igualmente o peso da responsabilidade. Pode-se imaginar o quanto, para uma criança como esta, o testemunho desse adulto, oferecendo algum amparo no convívio com a inexistência de certezas absolutas, é importante.

\subsection{Ecos literários. A formação no grande fluxo do discurso.}

Tornar-se, na vida, um leitor literário envolve, entre outros aspectos, adquirir, por experiência, uma compreensão em aberto sobre as questões humanas, a realidade, a própria subjetividade, fazendo um laço com essa abertura por meio de um desejo de transformação do próprio olhar, manifesto na vontade de ler mais um livro, e mais outro... Os ecos, promovidos ou não pelos próprios textos em sua intertextualidade intencional, dão testemunho da travessia das interrogações mais essenciais e sem resposta por um espaço da produção cultural que o leitor pode aprender a não querer vencer, transformando-se em um erudito conhecedor de repertório, mas antes explorar. Nesse movimento, ele igualmente poderá sentir-se um explorador na própria vida, tanto por dentro como por fora, nas suas relações com os outros. Tendo se afeiçoado à literatura, ele será levado a buscar e talvez encontre ajuda nas histórias, poemas, dramas, que lançam luzes sobre o seu próprio percurso e o dos demais. Luzes parciais sempre, mas que se tornam, para os amantes da leitura, muito significativas e até 
mesmo necessárias, ao lado de outras formas de compreender. As duas situações de leitura que acabamos de expor e comentar trazem marcas de contatos que podem fazer com que a leitura venha a ser algo que pertença à vida futura de alguns dos alunos dessa turma. A esse respeito, vale a pena ainda relembrar duas situações ocorridas em momentos posteriores ao aqui relatados.

Ao final do ano de 2018, depois de terem lido juntos em torno de cinquenta livros, a professora fez uma enquete com os seus alunos, perguntando a cada um que livro, entre todos, lhe tinha ficado marcado. Propositadamente disse marcado, não perguntando de que livro os alunos tinham gostado mais. A árvore generosa foi o segundo mais votado, ultrapassado apenas por Onde vivem os monstros (SENDAK, 2009), cuja leitura dera origem ao projeto de confecção de um livro, sobre o qual já nos referimos ${ }^{6}$.

No ano de 2019, Denise acompanhou a turma promovida do segundo para o terceiro ano do ensino fundamental. Fez isso por interesse em permanecer mais um tempo com o grupo, estimulada, entre outros motivos, pelo amadurecimento dos alunos nos processos de leitura. Ao lado das leituras compartilhadas em que a professora oraliza os textos, este ano os alunos se encarregam revezadamente da narração de obras da sua escolha, e há leituras realizadas pelos pais ou familiares das crianças, periodicamente. Além disso, a chegada de uma profissional para a sala de leitura da escola facilitou a circulação dos livros, e alguns alunos tornaram-se leitores assíduos.

No que se refere a A Árvore das lembranças, a retomada da leitura deu lugar a um novo diálogo, desta vez de uma única aluna com a professora. Em determinado dia de trabalho, enquanto uma parte da turma havia saído para uma aula de reciclagem de materiais, a outra ficou em sala, fazendo atividades livres. Gabriela pegou A árvore das lembranças e começou a ler junto com Lívia. Depois disso, veio até a mesa da professora para conversar.

Gabriela: Tia, eu tenho muitas dúvidas sobre este livro!

Prof : Que dúvidas?

Gabriela: Eu acho que ela morreu e virou uma árvore onde todo mundo foi morar. Daí ficam lembrando dela. Virou uma árvore da esperança.

Prof $^{a}$ : Então, qual sua dúvida?

Gabriela: Eu quero saber a verdade.

Prof $f^{a}$ : Que verdade?

Gabriela: Se ela morreu mesmo.

Prof : Mas você já não me deu sua opinião? Tem alguma outra opinião que poderia ser?

${ }^{6}$ O artigo "Onde Vivem os Monstros: leitura literária e seus percursos discentes" que narra o processo de criação do livro da turma, encontra-se publicado no livro FEARJ: debates sobre politicas, currículo e docência na alfabetização/ organizado por Claudia de Souza Lino [et al.]. - Rio de Janeiro, 2019. 
Gabriela: Ela poderia ter dormido e estar viva mesmo e nasceu uma árvore dela.

Prof : Olha só, Gabriela, eu também tenho uma opinião sobre o livro. Pra mim, a raposa morreu e onde ela morreu nasceu uma árvore e a árvore serve de uma boa lembrança para os amigos. Quando a gente perde alguém que a gente ama, no início dói muito, mas depois a dor vai se transformando em saudade. A dor passa, mas a saudade fica pra sempre.

Gabriela: Igual ao meu pai. Ele morreu quando eu era mais pequena, mas eu sinto falta dele. Não dói, não, só tenho saudade. Que bom que ele e a raposa estão num lugar melhor que a gente. Você acha tia?

Prof ${ }^{a}$ : Pode ser que sim, eu consigo acreditar nisso...

Mais uma vez observamos que é a "verdade" o que Gabriela vem buscar, mas ela encontra outra coisa. Palavras que permitem provisoriamente lidar, por meio de imagens, com o que nossos sentimentos não chegam a compreender. Mas não só isso. Há também uma voz, a voz de um outro que se sustenta igualmente em palavras e que pode destiná-las ao interlocutor como algo válido, como algum saber conjugado com um não-saber que, compartilhados, permitem habitar esse espaço em que a verdade não está. E aqui aprendemos algo sobre a utilidade da literatura e seu lugar no ambiente escolar, questão condutora deste trabalho. Sem oferecer respostas cabais, os textos literários podem de fato oferecer a cada momento algum tipo de resposta, mas isso desde que nesses escritos aprendamos a ouvir outros humanos, diante das mesmas questões que nos assolam. Antes, porém, que sejamos capazes de nos bastar como leitores solitários num diálogo que se faz à distância, e em que nós mesmos devemos suprir o que falta nessa situação de interlocução, a voz de um outro leitor que compartilha nossas interrogações parece ser necessária. Assim, do mesmo modo que, para Denise, as vozes dos colegas professores no grupo de formação puderam fazer com que os textos passassem a ter outro sabor, para Gabriela, e para os colegas da turma, a professora segue como um norte em seu processo de amadurecimento como leitores e como seres humanos.

No diálogo transcrito, também encontramos pistas para um trabalho posterior, em torno do status de realidade das ficções. O que aconteceu ou deixou de acontecer com a raposa da história pertence a uma obra de ficção. A dúvida da aluna pode ter a ver com isso, mas talvez o mais interessante da situação descrita seja o fato de que a leitora tenha podido construir, junto com a professora, um entendimento que respondesse à sua angústia. Um outro encaminhamento para a questão sobre a verdade por ela colocada poderia ser o da religião, que, no entanto, o texto não autoriza. Embora a aluna faça alusão a algo dessa natureza, percebemos que a professora, pondo de lado sua própria fé ou ausência dela, não reforçou o 
fechamento da compreensão em torno disso; ao contrário, buscou apenas auxiliar a criança a enunciar sua própria resposta para a questão colocada. Ao fazê-lo, exercitou com destreza um discernimento sempre exigente aose realizar a mediação entre o texto e o leitor.

\section{Considerações finais}

Nas conversas literárias aqui relatadas, em que cada criança entra com seu saber da leitura e também da vida, as aprendizagens incluem mas ultrapassam em muito o desenvolvimento de capacidades de compreensão leitora, se por leitura se entende um saber técnico, que pode ser colocado a serviço de qualquer objetivo prático. Constatamos que, nos diálogos em torno da literatura, um discurso da humanidade sobre si, algo de ordem existencial se move, a que a história registrada como texto dá lugar. O dispositivo da leitura compartilhada, em seu entretecimento dialógico, oferece aos sujeitos em formação uma rede capaz tanto de provocar o deslocamento de certezas como de amparar cada um no trajeto de sua inserção nas dimensões mais cruas da existência humana. A professora, nesse espaço de mútua formação, tem um papel fundamental, que ultrapassa os limites da instrução técnica e igualmente os da oferta de momentos de deleite. Trata-se de educação em seu sentido pleno. Algo que um trabalho responsável com o que é próprio da literatura pode ajudar a garantir na formação escolar.

Na leitura compartilhada, não só os textos se expandem, como sublinha Colomer (2007), expande-se também o convívio na diferença, fundamento do laço social. Nessa dinâmica, a múltipla apropriação dos textos literários, dando ensejo a concertos e contrastes, descobre a própria multiplicidade do mundo que compartilhamos, vivo e diverso e nunca homogêneo - o que, politicamente, pode capturar nosso desejo e merecer nosso empenho por guardar e garantir a riqueza da contribuição de todos. Isso vai de encontro a outras tendências presentes nos discursos sobre a educação no Brasil atual, em que, sob pretexto de defesa dos valores familiares, se busca o silenciamento das vozes e dos conflitos, em nome de uma pretensa neutralidade técnica que mal disfarça um projeto de submissão ao mercado e de manutenção das desigualdades. Nesse campo de luta em que, na escola, assim como fora dela, está em jogo a liberdade, é que nos inserimos, como professoras que praticam e defendem a leitura literária na formação escolar e universitária.

\section{Referências}


BAJOUR, Cecília. Ouvir nas entrelinhas: o valor da escuta nas práticas de leitura. São Paulo: Editora Pulo do Gato, 2012.

BRASIL. Secretaria de Educação Básica. Diretoria de Apoio à Gestão Educacional. Pacto nacional pela alfabetização na idade certa: formação de professores no pacto nacional pela alfabetização na idade certa / Ministério da Educação, Secretaria de Educação Básica, Diretoria de Apoio à Gestão Educacional. Brasília: MEC, SEB, 2012.

CANDIDO, Antonio. O direito à literatura. In: CANDIDO, Antonio. Vários Escritos. $3^{\mathrm{a}}$. Ed. São Paulo: Duas Cidades, 1995, p.235-263.

COLOMER, Teresa. Andar entre livros: a leitura literária na escola. São Paulo: Global, 2007.

GRIMM, Jacob e Willhem. Cinderela. In: MACHADO, Ana Maria (org). Cinderela e outros contos de Grimm. Rio de Janeiro: Nova Fronteira, 1996, p. 7-23.

MARCUSCHI, Luiz Antonio. Produção textual, análise de gêneros e compreensão. São Paulo: Parábola, 2008.

PETIT, Michèle. A arte de ler ou como resistir à adversidade. São Paulo: Editora 34, 2008.

RESENDE, D.B.; Andrade L. T.; OLIVEIRA M. F. A. P. S. Onde vivem os monstros: leitura literária e seus percursos discentes. In LINO, C. de S. et al. FEARJ: debates sobre politicas, currículo e docência na alfabetização. Rio de Janeiro, 2019.

ROJO, Roxane; MOURA, Eduardo (org). Pedagogia dos Multiletramentos. São Paulo: Parábola, 2012.

ROJO, Roxane; BARBOSA, Jaqueline. Hipermodernidade, multiletramentos e gêneros discursivos. São Paulo: Parábola, 2015.

SENDAK, Maurice. Onde vivem os monstros. São Paulo: Cosac e Naify, 2009.

SIGNORINI, Inês (org.). Significados da inovação no ensino de língua portuguesa e na formação de professores. São Paulo: Mercado de Letras, 2007.

SILVERSTEIN, Shell. A árvore generosa. São Paulo: Cia das Letrinhas,2017.

TECKENTRUP, Britta. A árvore das lembranças. Tradução Marília Garcia. Rio de Janeiro: Rovelle, 2014.

TODOROV, Tzvetan. A literatura em perigo. São Paulo: Difel, 2009.

ZILBERMAN, R. Que literatura para qual escola, que escola para qual literatura? Revista do Programa de Pós-Graduação em Letras da Universidade de Passo Fundo, v. 5, n. 1, p. 9-20, jan./jun. 2009. 
Recebido em 20 de setembro de 2019. Aceito em 14 de novembro de 2019. 